\title{
Reaching out to the orchestra - Concert visits as a curricular link to extracurricular musical activities?
}

\author{
PETER MALL*
}

Scientific Advisor at evalag (Evaluationsagentur Baden-Württemberg), Frankfurt am Main, Germany

\section{THEMATIC ARTICLE}

Published online: July 19, 2020

(C) 2020 The Author(s)

\begin{abstract}
Visiting classical concerts as part of school activities has a long tradition in Germany but has always been controversial. The multi-case study Schools@Concerts aims in mapping different approaches of connecting school music education with classical concert visits in seven European countries. As part of this project, this article gives early insights into the Frankfurt case. Different perspectives on concert visits include students, teachers and concert hosts. After a short overview about the German discussion, the article gives a brief insight into the state curricula concerning concert visits and the school curriculum of the participating school. All participants have positive attitudes towards concert visits but also highlight the organizational effort of it. Both, teacher and host emphasize missing resources for preparing concerts. Although classical concerts do not meet the musical taste of the children, most of them show positive attitudes to concert visits. Therefore the study wants to encourage responsible stake holders to support concert visits, both in schools and orchestras.
\end{abstract}

\section{KEYWORDS}

music education, cooperative programs, outreach programs, young peoples’ concerts, Schools@Concerts, multi-case-study

\footnotetext{
*Corresponding author. E-mail: info@petermall.de
} 


\section{INTRODUCTION}

Visiting classical concerts as part of school activities is actively discussed and widely promoted in Germany (Große-Jäger, 1988; Gruhn, 1988; Schmid, 2014), but in general it is not part of German music education curricula. Still concert visits or cooperative projects are extracurricular events which need to be organized outside of the regular curricula. As part of the Schools@Concerts project, pupils of a 7th grade class of a school in Frankfurt visited a concert of the student orchestra of the HfMDK Frankfurt. This visit was accompanied by an interview with the teacher and a group discussion with students. Organizational aspects not only determined the teachers' preparation process, but also influenced the pupils' experiences. The article discusses the actual curricula of the state of Hesse concerning cultural participation, how concerts visits are being connected to the curricula in this special case and how they are organized by the teacher. It is based on current data as well as data from a previous study (Mall, 2016a, 2016b).

\section{YOUNG PEOPLES' CONCERTS BETWEEN ARTS EDUCATION AND EXPERIENCE}

The development of young people' concerts is from the very beginning accompanied by a discussion about their educational aims (Barth, 1906). Arts education has become part of school curricula and the aim was to go back to the origin of music - the concert hall - and let pupils experience it. The known concepts (Barth, 1906; Esser, Esterhues, \& Pretsing, 1927) build on the idea, that pupils have to be brought up to concert life and classical music and the concepts are therefore closely related to the music education curricula of the time. The aim of Barth (1906) and Esser et al. (1927) decidedly was to enable underprivileged students to experience classical concerts as their concepts especially addressed elementary schools ("Volksschulen") with the aim to enable the students to participate in this culture. ${ }^{1}$

With a financial crisis for both the cultural and the educational system at the end of the 1960s, a discussion about connecting school education with outreach activities started new but only with limited impact as orchestras at that time focused their outreach activities in providing more concerts for elderly people and in venues on the countryside. School educators on the other hand started a more general discussion about the value of classical concerts for young people (Große-Jäger, 1988; Gruhn, 1988).

Only in the 1990s orchestras nationwide started to engage themselves in outreach activities with the result that at the end of this decade almost every orchestra in Germany provided Young Peoples' Concerts (Stiller, 1999). But most of these concerts were still dominated by the same conceptions outlined by Barth (1906) or Esser et al. (1927; cf. Eberwein, 1998). This changed with the presentation of the project Rhythm is it (Mast \& Milliken, 2008), mainly influenced by Simon Rattle at the Berlin Philharmonic Orchestra. Since then, several new educational approaches were developed and discussed, including family concerts (Schwanse, 2003), concerts for pre-school children (Stiller, 2008), scenic interpretation of the opera (Brinkmann, Kosuch, Stroh, \& Ostrop, 2013) and others (Schneider, 2002). Also the aims of concerts for children and

\footnotetext{
${ }^{1}$ Reckwitz (2012) describes this concept as normative definition for culture.
} 
their practice field (Wimmer, 2010) are part of the discussion, as well as the impact of education activities are object to research (Mall, 2016b). Lately, the interconnectedness of school music and outreach activities was newly discussed (Voit, 2018). Wimmer (2018) as well as Mall \& Schwarz (2018) used the term black box, but with different backgrounds, to describe concert education as intersection of cultural outreach activities and music education.

\section{BENEFITS OF PREPARING CONCERT VISITS AT SCHOOL}

Apart from a more general discussion about educational aims of classical concerts in the context of school music curriculum, the question arises, why and to what extend concerts should be prepared in school. While German educators for a long time still highlighted the general benefit and the cultural obligation of classical concerts as part of school curriculum (e.g., Große-Jäger, 1982), the benefit of classical concerts on music education and vice versa is more critically discussed in the United States, where the benefit of concert visits is often seen in relation to organizational effort. Kimpton \& Lestz (1985) for example gives insights into a cooperation of a school with the local concert host, where students of the school have been attracted to join concerts through various school media channels. Additionally, the concerts have been prepared with the musical preferences of children in mind in order to provide them a lively concert experience. Besides pieces of so called great composers the program promoted the theme of Star Wars. Others also recommend, that concerts on the one hand should be prepared at school but on the other hand concert hosts also should have educational needs in mind when preparing programs (Felder, 1998).

While this discussion highlights the question of how young peoples' concerts could influence and benefit music education in schools, younger studies start focusing on the question of concert education as part of children's cultural participation (see also Krupp-Schleußner, 2017), how schools can support it and to what extend classical concerts should be part of it. In a study about family concerts, Ulrike Schwanse (2003) showed that preparing concerts at primary school significantly increases the participation of families with lower income at family concerts. And the idea of providing children the chance of participating at classical concerts can be part of the motivation of school music teachers (Mall, 2016b). Also, the different aspects of irritation Andreas Bernhofer (2016) found in his study, can be addressed through school music education.

To better understand concert visits as part of (school) music education, the next chapters focus on existing curricula as well as school curricula and aims of school teachers.

\section{CURRICULAR BACKGROUND}

The core curriculum in the state of Hesse promotes competence oriented learning. Competences are understood as a connection between knowledge and ability (Kultusministerium, 2011, p. 5). Besides music specific competences, general competences (personal, social, learning and communication) are an important part of every field of learning.

The curriculum of the state of Hesse defines music as an essential part of human culture (Kultusministerium, 2011, p. 11) and school education should support children to experience music and to be able to express themselves musically (p. 11). The competence areas, described in 
the core curriculum are: listening to, making and ${ }^{2}$ transforming music and give children access to musical cultures. These fields of competences relate to the concept of Aufbauender Musikunterricht (constructive music learning), described by Jank (2013) and Fuchs (2015). Part of this curriculum is the term musikalische Gebrauchspraxen (musical fields of practice) and the request, to give children access to different (foreign) fields of musical practice. The aim is to give children access to cultural plurality and give them the chance to compare unfamiliar with familiar musical impressions and reflect and communicate about music (Kultusministerium, 2011, p. 11). Active participation in internal and external events, focused on esthetic experiences shall enable children to develop the intended competences (p. 13).

Classical concerts are not mentioned separately and teachers therefore are free to decide, weather classical concerts should be part of their individual curriculum or not. A previous study about concert education (Mall, 2016a) showed as well as the interviews in this study, that many teachers believe in the importance of giving children the chance to at least once have the chance to take part in a classical concert. This is connected to the fact, that more than half of the children that have taken part in this project are not having previous experiences with classical concerts.

While the school teacher in this project highlights the aspect of cultural participation, a university professor also interviewed decidedly connects concert visits with the competence field of listening to music. School preparation shall therefore enable students to listen to the music carefully and recognize and enjoy the music during the live concert. Both concepts take into account that pupils without pre-knowledge of concerts probably will be overwhelmed by this experience.

\section{School curriculum}

Based on the standard curriculum, schools substantiate themes and topics into a school curriculum in order to ensure that commonly agreed topics are being covered by every teacher of the school. The school in this project explicitly names visits of concerts in it's school curriculum connected to the field of musical environment. Other topics in this field are the music industry and professional music life. This connection is explicitly named in the curriculum for level 5 , in other levels it is part of general activities.

This short overview shows, that joining (classical) concerts as part of school music education is not clearly implemented into the school curricula. Music education aims to include surrounding cultural practices and give children the opportunity to take part in these practices. It therefore depends on the teachers focus and the schools priorities which role classical music plays, especially as there is and was a lively discussion about educational values of classical music in general. The collected data in this study (see next chapter) as well as those of previous studies (Mall, 2016b) shows that still many teachers see classical music as part of our society and that less children get in contact with it through their families or pre schools. Those teachers see school music education responsible to give children insights in all parts of our cultural heritage.

\section{SCHOOLS@CONCERTS - FRANKFURT a.M. (GERMANY)}

As part of this multi-case study a 7th grade class with 24 children from a grammar school (Gymnasium) in Frankfurt has visited a concert of the students orchestra of the University for

\footnotetext{
${ }^{2}$ This article generally refers to the curriculum of the German state of Hesse. As education in Germany is not federal legislation, every state has different curricula.
} 
Music and Performing Arts Frankfurt. The concert had the title Classic Masters and included works of Mozart, Beethoven and Schubert. The author visited the class prior to the concert to give a small introduction to the concert and after the concert for a small discussion round. During these visits, the student data for this case study (questionnaire and group discussion) were collected.

The visit of the class at the concert consisted of two parts. First, the children participated in lessons given at the University to students. Three groups of children visited two different lessons each with a small break in-between. The concert itself was the second part of the afternoon, starting at $7 \mathrm{pm}$.

The viewpoints of this case study not only include the students perspective, but also the perspectives of the teacher and the concert host. As this article focuses more on a general overview, the following individual perspectives are only briefly part of it.

\section{Students}

The class that participated in the project consisted of 24 pupils (13 male, 7 female, 4 others) with the average age of 12. Almost all children prefer Pop and Rap/Hip Hop music. One third of the children say that they like classical music. Other genres do not show any significant tendency with only soundtrack/theme song being liked (best three categories) by about two-thirds of the children. Six pupils play an instrument and 11 visited at least one classical concert during the last year. Interestingly, 20 children say that they like concerts in general but only four expect, that they will like this concert in particular. With some local differences, the answers of this questionnaire do not show significant differences between the different cases in the case study.

After the concert, the pupils filled out a questionnaire where they were asked to give 20 memories of the concert event. The answers correlate with the findings of Bernhofer (2016), showing that besides the musical experiences, the event was dominated by many other experiences, including conflicts with the elderly audience.

The findings so far indicate, that the pupils seem to recognize classical music as part of their cultural environment and generally enjoy concerts. Also did they very much honor the performance of the student musicians. As an effect of the evening concert the pupils were mostly exhausted from a long school day and could not enjoy the event as they might have done in other contexts.

\section{Teacher}

The teacher of this class has been interviewed after the project. She highlights different aims of concert visits. One major goal is to provide children the experience of a classical live concert. She believes, that concerts should be part of school music education. But the organization of concert visits is very difficult, as many people have to be involved, especially for concerts that take place outside school schedule.

Her preparation of concerts in school include information about the orchestra, the composer and the musical works played. An important part of the preparation process is to explain children how to behave with integrity in classical concerts as many children do not have previous experience with these situations.

The teacher confirms that the actual situation during the concert was difficult for the children. But including the circumstances, she thinks, that the children had a fruitful experience.

\section{Host}

Young peoples' concerts at the HfMDK Frankfurt serve two major aims of the institution: education and cultural participation. The main objective of the university obviously is education, 
here especially music teacher training. Therefore young peoples' concerts are organized with and through teacher training and the students get the chance to practically learn how concerts could be prepared at school. The other aim, cultural participation, wants to embed university live into society, enable participation of the surrounding community with the cultural potential of a music education institution. From this perspective, young peoples' concerts want to bring children in contact with culture and foster their interest in it.

Unfortunately, the resources for preparing concerts as well as preparing surrounding workshops are very limited. Processes have to fit into daily schedule and seminar structures. Therefore the HfMDK focuses these resources on the event of the Musik Monat Mai (musical month of may). As most of these activities are organized without extra payment, many participants (individuals as well as institutions) prefer events that trigger media interest. About five to six teachers per year ask for the possibility of joining seminars and having insight into the work at the university. This demand can be met and most classes then get the chance to join the seminars.

The host hopes that young peoples concerts in all the mentioned perspectives will get more resources that it would be possible to organize three to four concerts per year.

\section{DISCUSSION}

Joining live concerts not only means to listen to music, but it means to be part of a social event, which includes listening to music. Especially the answers of the children, but also previous research findings (Mall, 2015) show, that beside musical dimensions, also social and personal dimensions influence concert visits (Bernhofer, 2016), not only those of classical music. Teachers should be and are aware of this aspect during their preparation process. Maybe, especially those non musical factors make children enjoy concerts even if the music does not meet their preferred personal taste, which mainly is popular music. Also seeing real people play music and recognizing the effort they had to make this event possible seems to be a positive factor. But, highlighting the non-musical factors of life concerts open up even more questions about the aims of concert visits. Especially as they are rather difficult to organize (Felder, 1998), teachers and hosts should be well aware of their individual reasons as long national curricula do not provide clear frameworks and support systems.

This article can not answer these questions, but it can highlight, that all stake holders in this research process (teachers, children, hosts) have positive attitudes towards concert visits. Therefore, there are many reasons, to make the organization process for concert visits easier and support teachers in it. Further findings through the comparison of other cases in the underlying multi case study additionally may help to integrate this case into a greater picture of concert education partnerships.

Ethics: The study procedures were carried out in accordance with the Declaration of Helsinki. The study is approved by the State Ministry of Education of the state of Hesse.

Funding sources: The author received no funding for this research.

Authors' contribution: The manuscript was only written by the author. No other author did contribute to the manuscript. 
Conflict of interest: The authors declare no conflict of interest.

\section{ACKNOWLEDGMENTS}

No additional acknowledgements.

\section{ABOUT THE AUTHOR}

Peter Mall: Studied guitar in Kassel and Trossingen and received his diploma in 1999. He worked in music schools as guitar teacher before he started a PhD in 2010. His research about orchestral education was funded by the State Graduate Funding Program. He finished his theses with the title 'Orchestras and Schools' in 2015. He was research assistant at the HfMDK Frankfurt a.M., first at the EU program "Sounding Ways into Mathematics" (2015-17) and developed then an evaluation system for the university. Since 2019 he working at evalag as scientific advisor. He has been teaching music education at the HfMDK Frankfurt, HfMDK Mannheim and the HMTM Hannover.

\section{REFERENCES}

Barth, R. (1906). Die Jugend im Konzert und in der Oper. Kunsterziehung, 3, 95-106.

Bernhofer, A. (2016). Young people experiencing classical concerts. In O. Krämer \& I. Malmberg (Eds.), Open ears - Open minds. Listening and understanding music (pp. 323-336). Innsbruck: Helbling.

Brinkmann, R. O., Kosuch, M., Stroh, W. M., \& Ostrop, A.-K. (2013). Methodenkatalog der szenischen Interpretation von Musik und Theater (Neuaufl). Handorf: Lugert.

Eberwein, A. (1998). Konzertpädagogik. Konzeptionen von Konzerten für Kinder und Jugendliche. Hildesheim: Univ.-Bibliothek.

Esser, B., Esterhues, J., \& Pretsing, K. (1927). Handbuch der Didaktik und Methodik des Musikunterrichts in der Volksschule im Anschluss an das 'Liederbuch für Schule und Haus'. Arnsberg, Westfalen: Stahl.

Felder, H. (1998). Improving young people's concerts. General Music Today, 11(2), 14-16. https://doi.org/ $10.1177 / 104837139801100205$.

Fuchs, M. (2015). Musikdidaktik Grundschule. Esslingen: Helbling.

Große-Jäger, H. (1982). Die Bedeutung der Orchester für die Bildung von Kindern und Jugendlichen. Das Orchester, 30(9), 736-739.

Große-Jäger, H. (1988). Konzerte für Kinder. Musik \& Bildung, 20(5), 392-398.

Gruhn, W. (1988). Konzerte für Kinder. Wilfried Gruhn im Gespräch mit Willi Gohl. Musik \& Bildung, 3, 186-192. Jank, W. (2013). Musik-Didaktik. Praxishandbuch für die Sekundarstufe I und II (5. ed.). Berlin: Cornelsen. Kimpton, J., \& Lestz, G. M. (1985). Selling young people on the symphony. Music Educators Journal, 72(1), 44-45. https://doi.org/10.2307/3396576.

Krupp-Schleußner, V. (2017). Kopfhörer rein, Welt aus." Individuelle Perspektiven auf musikalisch-kulturelle Teilhabe vor dem Hintergrund des cappability approach. In A. J. Cvetko \& C. Rolle (Eds.), Musikpädagogik und Kulturwissenschaft. 1. Aufl. (pp. 87-104). Münster and New York: Waxmann. 
Kultusministerium, H. (2011). Bildungsstandards und Inhaltsfelder - Das neue Kerncurriculum für Hessen. Wiesbaden: Gymnasium.

Mall, P. (2015). Schule und Orchester - Aspekte kooperativer Projektarbeit von Orchestern mit allgemeinbildenden Schulen als Zusammenspiel schulischer und außerschulischer Musikvermittlung - eine empirische Studie (Dissertation). Pädagogische Hochschule Freiburg.

Mall, P. (2016a). Orchestras and Schools. Teachers' and musicians' subjective theories on cooperative projects. In Presented at the 24th EAS conference.

Mall, P. (2016b). Schule und Orchester. Aspekte des Zusammenspiels von schulischer und außerschulischer Musikvermittlung in kooperativer Projektarbeit. Augsburg: Wißner.

Mall, P., \& Schwarz, R.-O. (2018). Musikvermittlung aus soziologischer Perspektive. In J. Voit (Ed.), Zusammenspiel? Musikprojekte an der Schnittstelle von Kultur- und Bildungseinrichtungen. Sonderheft 9 Diskussion Musikpädagogik (pp. 18-30). Hamburg: Hildegard-Junker-Verlag.

Mast, C., \& Milliken, C. (2008). Zukunft@BPhil. Die education-projekte der berliner philharmoniker. Book, Mainz: Schott.

Reckwitz, A. (2012). Die Transformation der Kulturtheorien: zur Entwicklung eines Theorieprogramms (Studienausg., Nachdr. der Erstausg. 2000, 3. Aufl). Weilerswist: Velbrück Wiss.

Schmid, S. (2014). Dimensionen des Musikerlebens von Kindern. Theoretische und empirische Studie im Rahmen eines Opernvermittlungsprojektes. Augsburg: Wißner.

Schneider, E. K. (2002). Vermttittlung und Präsentation in Konzerten für Kinder. In B. Stiller, C. Wimmer, \& E. K. Schneider (Eds.), Spielräume musikvermittlung. Book section.

Schwanse, U. (2003). Familienkonzerte in Kooperation mit Grundschulen - ein Konzept und seine Wirkungen. Paderborn: Univ. Diss.

Stiller, B. (1999). Die Kinderkonzerte deutscher Orchester. Das Orchester, 47(9), 22-25.

Stiller, B. (2008). Erlebnisraum Konzert. Prozesse in der Musikvermittlung in Konzerten für Kinder. Regensburg: ConBrio.

Voit, J. (2018). Tagung Zusammenspiel? Sonderheft Diskussion Musikpädagogik.

Wimmer, C. (2010). Exchange. Die Kunst, Musik zu vermitteln. Salzburg: Stiftung Mozarteum. Retrieved from https://www.miz.org/dokumente/2010_November_Mozarteum_Studie\%20Musikvermittlung.pdf.

Wimmer, C. (2018). Artistic Citizenship. Wie agieren Musikerinnen und Musiker in der Musikvermittlung? In J. Voit (Ed.), Zusammenspiel? Musikprojekte an der Schnittstelle von Kultur- und Bildungseinrichtungen. Sonderheft 9 Diskussion Musikpädagogik (pp. 83-89). Hamburg: HildegardJunker-Verlag.

Open Access statement. This is an open-access article distributed under the terms of the Creative Commons AttributionNonCommercial 4.0 International License (https://creativecommons.org/licenses/by-nc/4.0/), which permits unrestricted use, distribution, and reproduction in any medium for non-commercial purposes, provided the original author and source are credited, a link to the CC License is provided, and changes - if any - are indicated. 